\section{Zrinka}

\section{Blažević}

Odsjek za povijest Filozofskog fakulteta Sveučilišta u Zagrebu

DOI: 10.17685/Peristil.61.15

\title{
Ivana Prijatelj Pavičić Schiavoni: umjetnici, nacija, ideologija
}

\author{
Jesenski i Turk
}

Zagreb, 2018. 365. str.
Recenzenti: Ivo Babić, Inoslav Bešker

ISBN 978-953-222-813-7

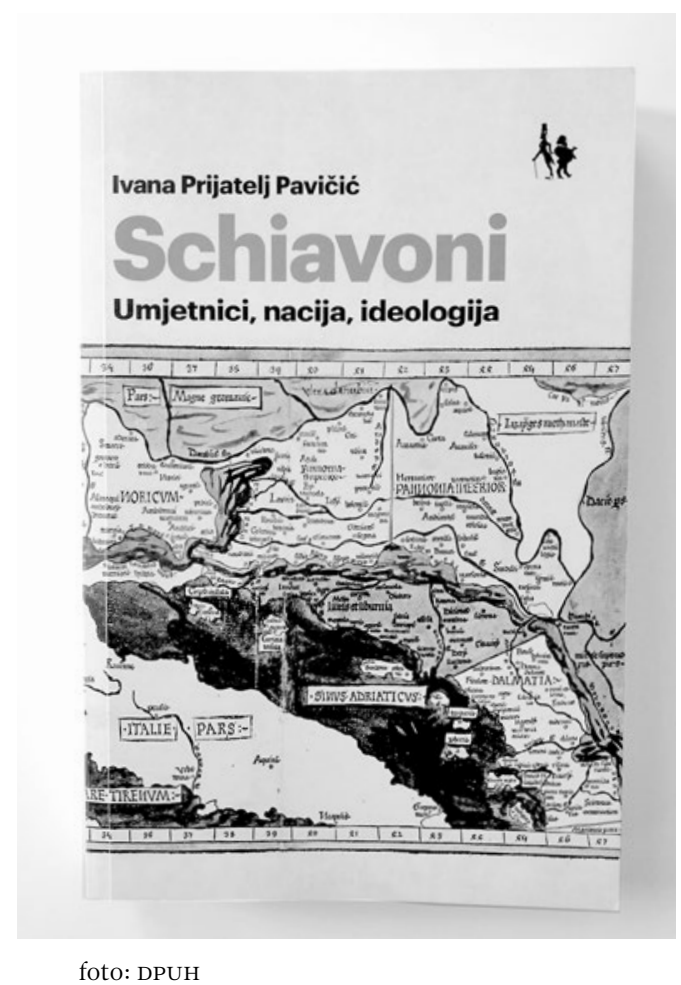

Danas, u doba jačanja konzervativnih naciocentričkih narativa, knjiga koja već u svome naslovu hrabro ističe prilično problematičnu etnonacionalnu odrednicu „Schiavoni“ sama je po sebi određeni kritičko-politički statement. Dakako, proporcionalno stupnju provokativnosti, koji već na prvi pogled izaziva, rastu i epistemički zahtjevi kojima djelo s takvim ambicijama mora udovoljavati kako bi uspješno prošlo kroz retortu znanstvene verifikacije.

Knjiga Ivane Prijatelj Pavičić na taj je izazov odgovorila na najbolji mogući način, predstavljajući u konceptualnom, teorijskom i interpretativno-analitičkom pogledu doista uzoran primjer intelektualno-povijesne i povijesno-umjetničke studije. Upravo je interdisciplinarnost, u koju se većina humanističkih znanstvenika zaklinje, ali ju je malo tko kadar egzemplificirati u vlastitim radovima, glavna odlika ovoga djela koje bi zasigurno ponosno prisvojili i povjesničari i povjesničari umjetnosti. Osim najboljih kritičko-analitičkih tradicija obiju povijesnih disciplina, autorica kreativno fuzionira i teorijsko-metodološke postulate $\mathrm{i}$ istraživačke rezultate znanstvenokritičkih paradigmi kao što su imagologija, balkanizam, orijentalizam i postkolonijalna teorija. To je rezultiralo izvrsnom metapovijesno-umjetničkom analizom koja će zasigurno postati oglednim primjerom 
„pragmatičkoga“ obrata u povijesnim znanostima. Stavljajući u analitički fokus kritičku fortunu likovnih umjetnika koji su u talijanskoj kulturnoj domeni zbog svoga istočnojadranskog podrijetla nazivani Schiavonima, Ivana Prijatelj Pavičić u pravoj eruditskoj maniri ispituje njezine ideološko-političke upotrebe, funkcije i značenja u dugom, polumilenijskom povijesnom trajanju. $\mathrm{Bu}-$ dući da su umjetnici Schiavoni ugradeni u temelje umjetničkoga kanona od njegovih humanističkih početaka do danas, povijesno-umjetnička recepcija umjetnika Schiavona je, kako s pravom uočava autorica, izvrsno ogledalo mijena ideoloških i epistemoloških paradigmi, ali auto- i heteropredodžbi o južnim Slavenima, Hrvatima, Dalmatincima i Morlacima, kao konstutitivnih elemenata nacionalno-identitetskih konstrukcija. Naime, humanistički žanr viri illustres koji je instituirao Francesco Petrarca, a prigrlili humanistički biografi poput Bartolomea Facija, Johannesa Trithemiusa i Giorgia Vasarija, imao je ključnu ulogu u kreiranju protonacionalnih ideologija poput romanizma, teutonizma i sarmatizma kao svojevrsno sredstvo kulturne legitimacije nacije. Ubrzo se prenosi i u ranonovovjekovni ilirizam gdje su, uz znamenite vojskovođe, u panteon nacionalnih heroja od samih početaka uključivani i intelektualci i umjetnici koji su civiliziranim svijetom pronosili slavu svoga naroda.

Paralelno s nastankom protonacionalnih ideologema, pojavljuju se, u formi mores gentis, i prve humanističke etnokarakterologije koje su predstavljale svojevrstan repozitorij osobina „nacija u nastajanju“. Pritom su se vlastitom nacionalnom kolektivu poglavito pridijevale pozitivno atribuirane aksiološke osobine, a „Drugima“, dakako, ponajviše one negativne. Time je u okviru protonacionalnih ideologija uspostavljena plodonosna poveznica između ideje individualne i kolektivne izvrsnosti koja je svoj vrhunac doživjela u romantičarskom kultu genija. Na tim je temeljima izgrađen i nacionalni književni, ali i umjetnički kanon čije su kontrafore, zbog svoje iznimne povijesne i simboličke vrijednosti, predstavljali upravo umjetnici Schiavoni. Kako je imanentna karakteristika svake nacionalne ideologije unutarnja inkluzivnost i vanjska ekskluzivnost, od početka 19. stoljeća umjetnici Schiavoni postaju objektom različitih i višesmjernih borbi za simboličku aproprijaciju. Fenomenologija i dinamika tih borbi zorno je odražavala ideološko-političke zahtjeve i legitimacijske potrebe različitih nacionalnih ideologija koje su se od sredine 19. stoljeća do danas nastojale nametnuti na južnoslavenskom prostoru kao ekskluzivni tumači i čuvari nacionalne tradicije i kulture.

U meandre tako zahtjevnog istraživanja kakvog bi se poduhvatio malo koji povjesničar, Ivana Prijatelj Pavičić uronila je s intelektualnom hrabrošću i eruditskom strašću pasioniranog znanstvenika koji se ne libi beskompromisno dekonstruirati čvrsto ukorijenjene nacionalne mitove. Svoju analizu opravdano započinje kritičkom raščlambom historiografski uvriježenih kroatiziranih inačica imena i prezimena najeksponiranijih umjetnika Schiavona poput Andrije Medulića, Julija Klovića, Jurja Ćulinovića, Ivana Duknovića i Federica Benkovića. Naime, prema tradicionalnom naciocentričkom shvaćanju, esencija nacionalnog identiteta umjetnika supsumirana je upravo u njihovim osobnim imenima koja usto predstavljaju i najsigurniji indikator njihove zavičajne, odnosno nacionalne pripadnosti.

Recepcijsku sudbinu umjetnika Schiavona autorica nadalje prati od prvih kritičkih evaluacija njihovih suvremenika do kraja 18. stoljeća, kada se počinju nazirati prve naznake njihove znanstvene kanonizacije. Osim inovativnog uvida da njihova kritička fortuna vjerno refletira strukturu suvremenih (proto)nacionalnoideologijskih koncepcija te etnokarakteroloških stereotipa i mitova, Ivana Prijatelj Pavičić u najboljoj novohistorističkoj maniri upozorava i na činjenicu da su modaliteti i mehanizmi njihova vlastita samopredstavljanja uvelike bili usklađeni s dominantnim ideologemima njihova vremena. O tome posebno indikativno svjedoči slučaj Julija Klovića koji je, sukladno kultnom statusu Aleksandra Makedonskog u okviru ideologije humanističkog ilirizma, svjesno gradio i podržavao predodžbu o svome makedonskom podrijetlu.

Iduće poglavlje knjige autorica je posvetila formativnom razdoblju kanonizacije umjetnika Schiavona koji u nacionalno-romantičarskoj interpretaciji Ivana Kukuljevića Sakcinskog postaju kontraforima južnoslavenskoga umjetničkog panteona. Otkada se njihovo umjetničko stvaralaštvo počinje tumačiti kao hipostazirani izraz kreativnoga „duha naroda“, započinje pobjedonosni naciotvorni uspon umjetnika Schiavona. Njihov je neprikosnoveni status u nacionalnoj kulturi definitivno potvrđen i ovjekovječen uvrštavanjem njihovih bista u „hrvatski Kapitol“, odnosno galeriju znamenitih muževa u perivoju na Zrinjevcu 
1879. godine.

Aproprijacija umjetnika Schiavona, koji su podrijetlom s istočnojadranske obale, u južnoslavenski nacionalni kanon izazvala je, sasvim očekivano, žestoku reakciju na strani dalmatinskih regionalista i autonomista. Podrobno prikazavši modalitete nesmiljene borbe oko njihove simboličke aproprijacije, Ivana Prijatelj Pavičić zaključuje kako su umjetnici Schiavoni sredinom 19. stoljeća postali snažan simbol nacionalnog identiteta. Stoga su zadobili trajno mjesto u političkim imaginariju na ovim prostorima, postavši dio historiografskog mita o narodnosnoj samosvojnosti, o povijesnome prostoru i povijesnome pravu na odredeni teritorij.

$\mathrm{S}$ tih su pozicija umjetnici Schiavoni ušli u razdoblje turbulentnog 20. stoljeća. Osim što su i dalje bili predmetom talijanskih, hrvatskih i jugoslavenskih nacionalnih i nacionalističkih aproprijacija, prevrednovanja, eksproprijacija i resemantizacija, autorica zorno pokazuje kako su postupno postajali i konstitutivnim elementom metanaracije znanstvene discipline povijesti umjetnosti. $\mathrm{Na}-$ ime, upravo na kritičkoj fortuni umjetnika Schiavona prelamala su se važna epistemološka pitanja povijesti umjetnosti poput prirode „narodnoga izraza i umjetničke volje“, odnosno problema socijalne, kulturne i prostorne determiniranosti likovne umjetnosti općenito. Inovacijske potencijale umjetnika Schiavona kao epistemološkog fenomena najbolje egzemplificira teorija o umjetničkom transferu Miroslava Krleže oblikovana početkom 1950-ih godina koja je nekoliko desetljeća anticipirala ključne postulate postkolonijalne teorije o „periferiji kao centru“.

Konačno, u posljednjem poglavlju ove odlične knjige Ivana Prijatelj Pavičić uvjerljivo dokazuje da su se, nakon različitih ideoloških, znanstvenih i političkih funkcija koje su obnašali tijekom svoje polumilenijske karijere neprikosnovenih kulturnih simbola, umjetnici Schiavoni uspješno uklopili i u nove zahtjeve koje su na dnevni red postavili aktualni trendovi kulturne komodifikacije i komercijalizacije i turističkog brendiranja. Time se umjetnici Schiavoni ukazuju kao vrsta neinflatornog simboličkog kapitala s dugoročnim prinosima te će u tom smislu biti zanimljivo pratiti i njihovu daljnju recepcijsku i reprodukcijsku sudbinu. Jednako bi tako i ovoj knjizi trebalo poželjeti što dugotrajniju i obuhvatniju recepciju i to, kako u krugovima intelektualnih i kulturnih povjesničara, tako i unutar ceha povjesničara umjetnosti.
Naime, knjiga Ivane Prijatelj Pavičić uvjerljivo svjedoči da je, uz kritički i autorefleksivan heuristički pristup, najbolji recept za prijeko potrebnu epistemološku obnovu ovih dviju, tradicionalno vrlo konzervativnih, znanstvenih disciplina s jedne strane njihovo međusobno interdisciplinarno fuziniranje, a s druge strane hrabra implementacija heurmeneutički učinkovitih teorijskih i metodoloških paradigmi. 